\title{
Metabolism of Tryptophan in Childhood Epilepsy
}

\author{
P. A. M. HUGHES, B. D. BOWER, D. N. RAINE, and N. SYED \\ From the Biochemistry Department, Birmingham Children's Hospital, Birmingham 16, and \\ Department of Paediatrics and Child Health, University of Birmingham
}

\begin{abstract}
A relation between pyridoxine and convulsive phenomena has been established over several years (Snyderman, Holt, Carretero, and Jacobs, 1953; Molony and Parmelee, 1954; Adams, Bessey, Bussey, and Hansen, 1954; May, 1954; Coursin, 1954, 1955). This led to a search for evidence of pyridoxine deficiency among children with cryptogenic epilepsy. Soon patients were discovered who, though receiving a normal amount of pyridoxine, stopped convulsing when given supplements of this vitamin and relapsed when these were withdrawn (Hunt, Stokes, McCrory, and Stroud, 1954; Bessey, Adams, and Hansen, 1957; Sokoloff, Lassen, McKhann, Tower, and Albers, 1959; Marie, Hennequet, Lyon, Debris, and Le Balle, 1959; Scriver, 1960; Garty, Yonis, Braham, and Steinitz, 1962; Waldinger and Berg, 1963; Scriver and Hutchison, 1963). This condition, named pyridoxine dependency, may be an inborn error of metabolism and should be distinguished from a dietary deficiency of the vitamin, which also results in convulsions.
\end{abstract}

Cochrane (1959) reported an apparent association of the form of childhood epilepsy known as infantile spasms ('lightning fits', 'massive myoclonic epilepsy', West's syndrome), with pyridoxine deficiency. The five patients he studied excreted more than the normal amount of xanthurenic acid following the administration of tryptophan, a finding in accord with pyridoxine deficiency, and on administration of this vitamin, 'a definite decrease in the frequency of their convulsions and an improvement in mental status was observed'. This was further investigated by Bower (1961) and Bower and Hughes (1961) who reported on the tryptophan load test in a small group of normal children; in a group of patients with infantile spasms (subdivided into those associated with some other disorder, 'symptomatic' and those without, 'cryptogenic'); and in a small group which included, without differentiation, children with other forms of epilepsy and mental deficiency. The results of this preliminary study suggested that half the children with cryptogenic infantile spasms

Received March 31, 1966. excreted more than the normal amount of xanthurenic acid, whereas all those in the symptomatic group were normal in this respect. Treatment with ACTH or corticosteroids, the favoured therapy, resulted in a reduction in the excretion of xanthurenic acid in all cases. Because of the relation of the biochemical abnormality to pyridoxine deficiency, the effect of giving this vitamin was examined but the clinical response in the few patients studied at that time was equivocal.

Following these preliminary results a more detailed study of tryptophan metabolism in this group of patients has been made and is the subject of the present report. A greater number of patients with infantile spasms has been studied in order to see whether the difference between the symptomatic and cryptogenic groups is real. Patients with other forms of epilepsy have been studied, in case the biochemical abnormality is related to the convulsions themselves, rather than to their several causes. The results of these two studies allow the evaluation of the tryptophan load test as a means of differentiating one aetiological group of spasms from another, and one clinical form of epilepsy from another. Since patients with infantile spasms are usually mentally retarded, a group of patients with mental retardation but without any evidence of epilepsy has been studied to examine the possibility that the biochemical abnormality is associated with mental subnormality rather than with epilepsy.

There is an apparent contradiction between the increase in xanthurenic acid excretion, indicating pyridoxine deficiency, and the failure of this vitamin to improve affected patients. Further evidence for the association of the biochemical defect with this vitamin has therefore been sought by studying several other pyridoxine-dependent metabolites of tryptophan. The value of the tryptophan load test in deciding between various forms of treatment and in determining their effectiveness will be considered in a later paper.

The present paper demonstrates that there is no difference in the frequency of abnormal tryptophan load tests between the symptomatic and cryptogenic 
Metabolism of Tryptophan in Childhood Epilepsy

TABLE I

Clinical and Biochemical Data in Healthy Controls

\begin{tabular}{|c|c|c|c|c|}
\hline $\begin{array}{l}\text { Group } 1 \\
\text { Subject No. }\end{array}$ & Age When Tested & Weight (kg.) & Diagnosis & $\begin{array}{l}\text { Metabolite Excretion } \\
\text { (mg./24 hr.) } \mathrm{XA}^{\star}\end{array}$ \\
\hline $\begin{array}{r}1 \\
2 \\
3 \\
4 \\
5 \\
6 \\
7 \\
8 \\
9 \\
10 \\
11 \\
12 \\
13 \\
14\end{array}$ & $\begin{array}{l}2 \mathrm{mth} . \\
2 \mathrm{mth} . \\
7 \mathrm{mth} . \\
7 \mathrm{mth} . \\
8.5 \mathrm{mth} . \\
11 \mathrm{mth} . \\
1 \mathrm{yr} .3 .5 \mathrm{mth} . \\
1 \mathrm{yr} .11 \mathrm{mth} \text {. } \\
2 \text { yr. } 1 \mathrm{mth} . \\
2 \text { yr. } 6 \mathrm{mth} . \\
3 \mathrm{yr} . \\
3 \text { yr. } 1 \mathrm{mth} . \\
3 \text { yr. } 4 \mathrm{mth} . \\
5 \text { yr. }\end{array}$ & $\begin{aligned} 4 \cdot 8 \\
3 \cdot 9 \\
5 \cdot 4 \\
5 \cdot 2 \\
6 \cdot 9 \\
9 \cdot 1 \\
11 \cdot 3 \\
9 \cdot 3 \\
12 \cdot 2 \\
12 \cdot 2 \\
14 \cdot 3 \\
14 \cdot 5 \\
11 \cdot 8 \\
17 \cdot 7\end{aligned}$ & $\begin{array}{l}\text { Oesophageal atresia } \\
\text { Post-bronchitis } \\
\text { Post-pneumonia } \\
\text { Post-urinary infection } \\
\text { ? Protein sensitivity } \\
\text { Post-bronchitis } \\
\text { Post-meningitis } \\
\text { Failure to thrive } \\
\text { Post-meningitis } \\
\text { Breath-holding attacks } \\
\text { Post-tuberculosis } \\
\text { Eczema } \\
\text { Dwarfism } \\
\text { Temper tantrums }\end{array}$ & $\begin{array}{l}1 \cdot 4 \\
2 \cdot 3 \\
1 \cdot 2 \\
1 \cdot 3 \\
1 \cdot 9 \\
0 \\
1 \cdot 3 \\
0 \cdot 8 \\
1 \cdot 8 \\
1 \cdot 6 \\
2 \cdot 4 \\
2 \cdot 7 \\
2 \cdot 3 \\
2 \cdot 6\end{array}$ \\
\hline
\end{tabular}

Note: In Tables I to $\mathrm{V}, \mathrm{XA}^{\star}=$ xanthurenic acid as determined by the ferric alum method; the remainder of the metabolites were determined after chromatographic separation, $\mathrm{XA}=$ xanthurenic acid, $\mathrm{K}=$ kynurenine, $\mathrm{KA}=\mathrm{kynurenic}$ acid, 3 - $\mathrm{OH} \mathrm{K}=3$-hydroxykynurenine, 3-OH AA = 3-hydroxyanthranilic acid.

TABLE II

Clinical and Biochemical Data in CNS Disorders Without Convulsions

\begin{tabular}{|c|c|c|c|c|c|c|c|c|c|c|c|}
\hline \multirow{2}{*}{$\begin{array}{c}\text { Group } \\
2 \\
\text { Subject } \\
\text { No. }\end{array}$} & \multirow{2}{*}{$\begin{array}{l}\text { Age When } \\
\text { Tested }\end{array}$} & \multirow{2}{*}{$\begin{array}{c}\text { Weight } \\
\text { (kg.) }\end{array}$} & \multirow[b]{2}{*}{ Diagnosis } & \multirow{2}{*}{$\begin{array}{l}\text { Mental } \\
\text { Status }\end{array}$} & \multirow[b]{2}{*}{ EEG } & \multicolumn{6}{|c|}{ Metabolite Excretion (mg. 24 hr.) } \\
\hline & & & & & & $\mathrm{XA}^{\star}$ & $\mathbf{X A}$ & $\mathbf{K}$ & $\mathbf{K A}$ & $\underset{\mathrm{K}}{3-\mathrm{OH}}$ & $\begin{array}{c}3-\mathrm{OH} \\
\mathrm{AA}\end{array}$ \\
\hline $\begin{array}{r}10 \\
1 \\
2 \\
13 \\
3 \\
17 \\
8 \\
4 \\
12 \\
9 \\
5 \\
16 \\
19 \\
6 \\
14 \\
15 \\
7 \\
18 \\
11 \\
20\end{array}$ & $\begin{array}{l}4 \mathrm{mth} . \\
9 \mathrm{mth} . \\
1 \mathrm{yr} . \\
1 \text { yr. } 1 \mathrm{mth} . \\
1 \text { yr. } 1 \mathrm{mth} . \\
1 \text { yr. } 6 \mathrm{mth} . \\
1 \text { yr. } 10 \mathrm{mth} . \\
1 \text { yr. } 10 \mathrm{mth} . \\
1 \text { yr. } 11 \mathrm{mth} . \\
22 \text { yr. } \\
2 \text { yr. } 1 \mathrm{mth} . \\
2 \text { yr. } 3 \mathrm{mth} . \\
2 \text { yr. } 8 \mathrm{mth} . \\
2 \text { yr. } 10 \mathrm{mth} . \\
3 \text { yr. } \\
3 \text { yr. } 10 \mathrm{mth} . \\
4 \text { yr. } 2 \mathrm{mth} . \\
5 \text { yr. } 6 \mathrm{mth} . \\
5 \text { yr. } 6 \mathrm{mth} . \\
1 \mathrm{yr} .\end{array}$ & $\begin{array}{r}4 \cdot 9 \\
6 \cdot 3 \\
12 \cdot 7 \\
9 \cdot 3 \\
7 \cdot 8 \\
9 \cdot 7 \\
8 \cdot 7 \\
13 \cdot 6 \\
11 \cdot 2 \\
11 \cdot 4 \\
7 \cdot 8 \\
10 \cdot 8 \\
11 \cdot 8 \\
11 \cdot 1 \\
13 \cdot 1 \\
12 \cdot 7 \\
15 \cdot 4 \\
16 \cdot 3 \\
16 \cdot 1 \\
8 \cdot 6\end{array}$ & $\begin{array}{l}\text { Hydranencephaly } \\
\text { Mental subnormality } \\
\text { Cerebral palsy } \\
\text { Spastic quadriplegia } \\
\text { Mental subnormality } \\
\text { Spastic paraplegia } \\
\text { Benign hypotonia } \\
\text { Cerebral palsy } \\
\text { Mental subnormality } \\
\text { Mental subnormality } \\
\text { Cerebral palsy } \\
\text { Spastic diplegia } \\
\text { Quadriparesis } \\
\text { Cerebral palsy } \\
\text { Ataxic diplegia } \\
\text { Lt. spastic hemiplegia } \\
\text { Ataxia } \\
\text { Spastic paraplegia } \\
\text { Mental subnormality } \\
\text { Cerebral atrophy- } \\
\text { mental subnormality }\end{array}$ & $\begin{array}{l}\mathrm{G} \\
\mathbf{G} \\
\mathbf{N} \\
\mathrm{G} \\
\mathbf{N} \\
\mathbf{M} \\
\mathbf{N} \\
\mathbf{M} \\
\mathbf{G} \\
\mathbf{M} \\
\mathbf{N} \\
\mathbf{N} \\
\mathbf{G} \\
\mathbf{M} \\
\mathbf{M} \\
\mathbf{N} \\
\mathbf{M} \\
\mathbf{M}\end{array}$ & $\begin{array}{c}\text { Flat } \\
\mathbf{N} \\
\mathbf{N} \\
\mathbf{N} \\
\mathbf{N} \\
\mathbf{N} \\
\mathbf{N} \\
\mathbf{N} \\
\mathbf{N} \\
\mathbf{N S A} \\
\mathbf{N} \\
\mathbf{N} \\
\mathbf{N} \\
\mathbf{N} \\
\mathbf{N} \\
\mathbf{t} \\
\mathbf{N} \\
\mathbf{N S A} \\
\mathbf{f} \\
-\end{array}$ & $\begin{array}{r}0.3 \\
0.6 \\
3.8 \\
0.9 \\
4 \cdot 7 \\
0.9 \\
3.3 \\
1.7 \\
16.5 \\
0.7 \\
9.3 \\
21.5 \\
8.6 \\
1.8 \\
2.3 \\
4.6 \\
2.5 \\
2.5 \\
13.2 \\
0.7 \\
0.7\end{array}$ & $\begin{array}{r}4 \cdot 5 \\
15 \cdot 5\end{array}$ & $\begin{array}{l}18 \cdot 2 \\
17 \cdot 3\end{array}$ & $\begin{array}{l}12 \cdot 3 \\
16 \cdot 9\end{array}$ & $\begin{array}{l}1 \cdot 0 \\
3 \cdot 1\end{array}$ & $\begin{array}{l}++ \\
++\end{array}$ \\
\hline
\end{tabular}

Mental status : $N=$ normal, $G$ and $M=$ gross and moderate retardation. $\quad \mathrm{EEG}: \mathrm{N}=$ normal, $\mathrm{NSA}=$ non-specific abnormality, $\dagger=$ single spike and wave discharge, $¥=$ spikes in occipital regions.

subgroups of patients with infantile spasms, nor between this and other forms of epilepsy. Furthermore, a substantial number of mentally retarded patients who have never suffered from convulsions show the same biochemical abnormality. The relation of the biochemical abnormality to pyridoxine, while not yet proved, is strengthened by the studies to be described.

\section{Material and Methods}

The subjects are divided into five groups.

Healthy controls (Group 1). This group consists of 14 children ( 9 boys, 5 girls) in hospital for reasons other than epilepsy and dietary deficiency. They were in good health at the time, those who had had an infection having made a good recovery. Their ages ranged from 2 months to 5 years (Table I).

CNS disorders without convulsions (Group 2). The details of these 20 patients (11 boys, 9 girls) are shown in Table II.

Epilepsy-other than infantile spasms (Group 3). (Henceforth called the epileptic group.) The details of these 46 patients (26 boys, 20 girls) are shown in Table III.

Infantile spasms-cryptogenic (Group 4). These 27 patients ( 20 boys, 7 girls) had an uneventful delivery and had developed normally until the onset of spasms, 
TABLE III

Clinical and Biochemical Data in Epilepsy other than Infantile Spasms

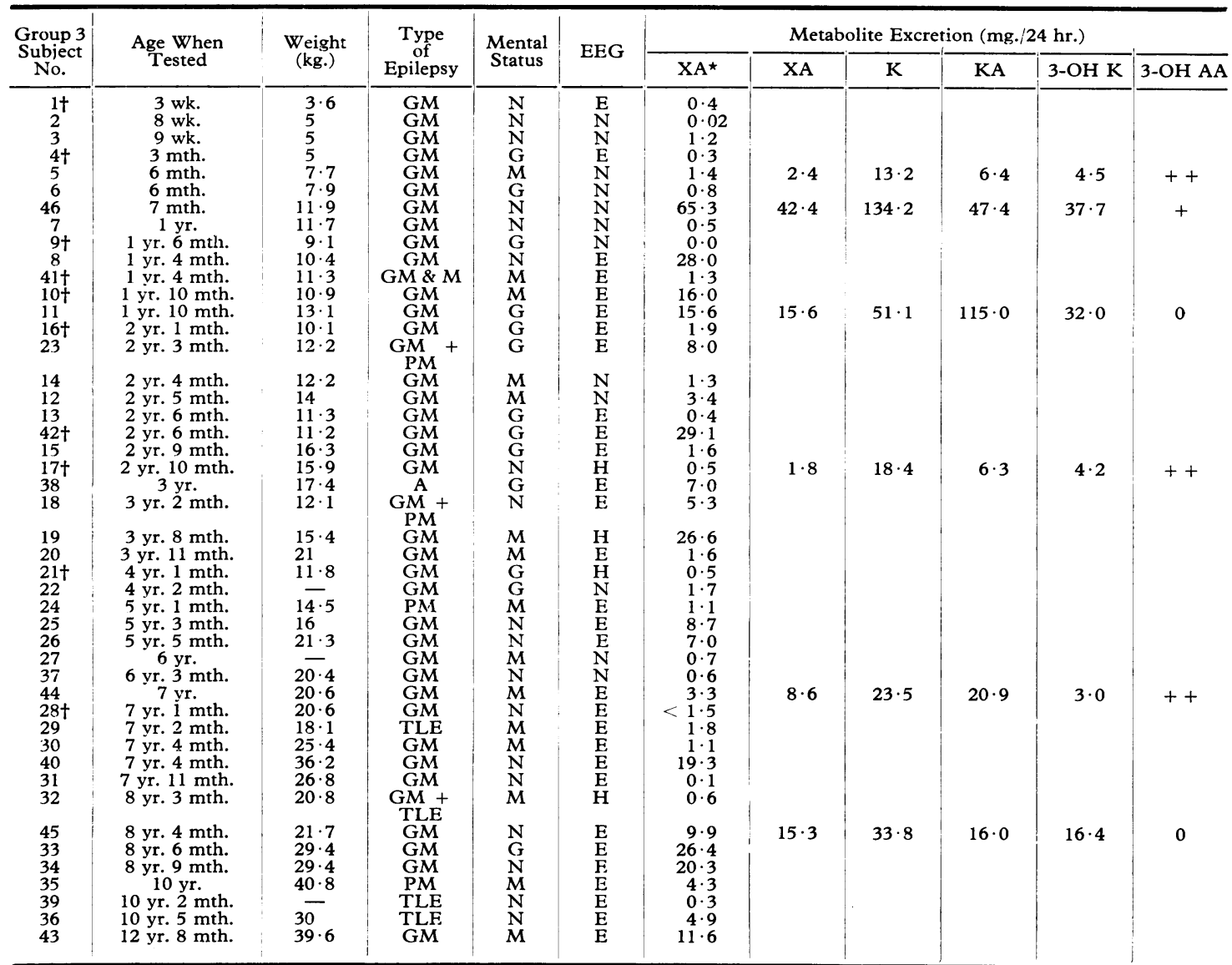

† Indicates that the subject suffered perinatal damage. Subject 15 suffered from metachromatic leucodystrophy.

Type of epilepsy: GM and PM = grand and petit mal, $\mathrm{A}=$ akinetic, TLE = temporal lobe epilepsy, $M=$ myoclonic seizures. EEG: $\mathrm{N}=$ normal, $\mathrm{F}=$ epileptic, $\mathrm{H}=$ hypsarrhythmia.

Mental status: as in Table II.

and no reason for these could be discovered on examination or by appropriate investigations (Jeavons and Bower, 1964). Their ages ranged from 3 months to 2 years 2 months. Details are shown in Table IV.

Infantile spasms-symptomatic (Group 5). In these 32 patients ( 25 boys, 7 girls) a definite or probable cause for the spasms and mental subnormality was found. The criteria for diagnosis are discussed elsewhere (Jeavons and Bower, 1964) and the cerebral insults are listed, together with other details, in Table V.

Urine was collected for 6-hourly periods, 12 hours before and 24 hours after an oral dose of L-tryptophan. (The mixture of D- and L-isomers was not used since the D-isomer is excreted unchanged or as the corresponding keto-acid.)
The dose of L-tryptophan (patients under 3 years, $200 \mathrm{mg}$. $/ \mathrm{kg}$., those over 3 years, $100 \mathrm{mg} . / \mathrm{kg}$.) was suspended in 2 fluid oz. (57 ml.) of flavoured water. This preparation was usually tolerated, but in a few patients vomiting occurred and the dose had to be repeated after a few hours. In two patients a convulsion occurred 3 hours after the administration. As these patients had previously had convulsions it is uncertain whether tryptophan played any part in causing these attacks.

Xanthurenic acid was determined by its reaction with ferric alum (modification of Bessey et al., 1957). In many cases simultaneous quantitative determinations were also made of xanthurenic acid, kynurenine, kynurenic acid, 3-hydroxykynurenine, and semiquantitative assessment of 3-hydroxyanthranilic acid, following separation of these metabolites by two- 
TABLE IV

Clinical and Biochemical Data in Infantile Spasms, Cryptogenic

\begin{tabular}{|c|c|c|c|c|c|c|c|c|c|c|}
\hline \multirow{2}{*}{$\begin{array}{c}\text { Group } 4 \\
\text { Subject } \\
\text { No. }\end{array}$} & \multirow{2}{*}{$\begin{array}{l}\text { Age When } \\
\text { Tested }\end{array}$} & \multirow{2}{*}{$\begin{array}{c}\text { Weight } \\
\text { (kg.) }\end{array}$} & \multirow{2}{*}{$\begin{array}{l}\text { Mental } \\
\text { Status }\end{array}$} & \multirow{2}{*}{ EEG } & \multicolumn{6}{|c|}{ Metabolite Excretion (mg./24 hr.) } \\
\hline & & & & & $\mathbf{X A}^{\star}$ & $\mathbf{X A}$ & $\mathbf{K}$ & $\mathbf{K A}$ & 3-OH K & 3-OH AA \\
\hline $\begin{array}{r}1 \\
3 \\
4 \\
2 \\
27 \\
5 \\
7 \\
23 \\
6 \\
8 \\
25 \\
9 \\
11 \\
10 \\
12 \\
13 \\
15 \\
14 \\
16 \\
24 \\
21 \\
17 \\
26 \\
19 \\
18 \\
20 \\
22\end{array}$ & $\begin{array}{l}3 \mathrm{mth} . \\
4 \mathrm{mth} . \\
4 \mathrm{mth} . \\
4 \mathrm{mth} . \\
4 \mathrm{mth} . \\
6 \mathrm{mth} . \\
7 \mathrm{mth} . \\
7 \mathrm{mth} . \\
7 \mathrm{mth} . \\
7.5 \mathrm{mth} . \\
7.5 \mathrm{mth} . \\
8 \mathrm{mth} . \\
8 \mathrm{mth} . \\
8 \mathrm{mth} . \\
9 \mathrm{mth} . \\
9 \mathrm{mth} . \\
9 \mathrm{mth} . \\
9 \mathrm{mth} . \\
10 \mathrm{mth} . \\
1 \mathrm{yr} . \\
1 \text { yr. } 1 \mathrm{mth} . \\
1 \text { yr. } 1.5 \mathrm{mth} . \\
1 \text { yr. } 2 \mathrm{mth} . \\
1 \text { yr. } 2 \mathrm{mth} . \\
1 \text { yr. } 2 \mathrm{mth} . \\
1 \text { yr. } 4 \mathrm{mth} . \\
2 \text { yr. } 2 \text { mth. }\end{array}$ & $\begin{array}{r}7 \\
5 \cdot 7 \\
6 \cdot 3 \\
7 \cdot 3 \\
6 \cdot 4 \\
8 \\
7 \cdot 5 \\
8 \cdot 2 \\
9 \cdot 1 \\
8 \cdot 7 \\
8 \cdot 7 \\
10 \cdot 4 \\
8 \cdot 4 \\
6 \cdot 8 \\
8 \cdot 8 \\
10 \cdot 7 \\
9 \cdot 3 \\
12 \cdot 9 \\
7 \cdot 9 \\
10 \cdot 3 \\
10 \cdot 4 \\
9 \cdot 4 \\
10 \cdot 9 \\
7 \cdot 9 \\
9 \cdot 7 \\
10 \cdot 9 \\
12 \cdot 1\end{array}$ & $\begin{array}{l}\mathbf{G} \\
\mathbf{G} \\
\mathbf{G} \\
\mathbf{G} \\
\mathbf{M} \\
\mathbf{M} \\
\mathbf{G} \\
\mathbf{G} \\
\mathbf{G} \\
\mathbf{M} \\
\mathbf{G} \\
\mathbf{M} \\
\mathbf{G} \\
\mathbf{M} \\
\mathbf{M} \\
\mathbf{G} \\
\mathbf{G} \\
\mathbf{G} \\
\mathbf{G} \\
\mathbf{G} \\
\mathbf{G} \\
\mathbf{G} \\
\mathbf{G} \\
\mathbf{G} \\
\mathbf{G} \\
\mathbf{M}\end{array}$ & $\begin{array}{l}\mathbf{E} \\
\mathbf{H} \\
\mathbf{H} \\
\mathbf{H} \\
\mathbf{E} \\
\mathbf{H} \\
\mathbf{H} \\
\mathbf{H} \\
\mathbf{H} \\
\mathbf{H} \\
\mathbf{H} \\
\mathbf{H} \\
\mathbf{E} \\
\mathbf{H} \\
\mathbf{H} \\
\mathbf{E} \\
\mathbf{H} \\
\mathbf{E} \\
\mathbf{E} \\
\mathbf{H} \\
\mathbf{E} \\
\mathbf{H} \\
\mathbf{E} \\
\mathbf{H} \\
\mathbf{H} \\
\mathbf{H} \\
\mathbf{H}\end{array}$ & $\begin{array}{l}0 \cdot 2 \\
0 \cdot 1 \\
0 \cdot 4 \\
0 \cdot 6 \\
0 \cdot 4 \\
0 \\
0 \cdot 4 \\
1 \cdot 4 \\
1 \cdot 0 \\
0 \cdot 1 \\
0 \\
3 \cdot 5 \\
1 \cdot 6 \\
1 \cdot 2 \\
1 \cdot 9 \\
3 \cdot 9 \\
0 \cdot 1 \\
18 \cdot 7 \\
1 \cdot 7 \\
1 \cdot 2 \\
7 \cdot 2 \\
2 \cdot 7 \\
26 \cdot 4 \\
3 \cdot 0 \\
1 \cdot 3 \\
6 \cdot 0 \\
16 \cdot 1\end{array}$ & $\begin{array}{l}0 \cdot 8 \\
3 \cdot 8 \\
1 \cdot 2 \\
\\
4 \cdot 2\end{array}$ & $\begin{array}{l}9 \cdot 8 \\
9 \cdot 9 \\
0 \cdot 3\end{array}$ & $\begin{array}{r}5 \cdot 1 \\
22 \cdot 3 \\
4 \cdot 3\end{array}$ & $\begin{array}{l}2 \cdot 7 \\
5 \cdot 6 \\
0\end{array}$ & $\begin{array}{l}t+ \\
+t \\
+t\end{array}$ \\
\hline
\end{tabular}

EEG, mental status, and metabolites as in Tables I-III.

TABLE V

Clinical and Biochemical Data in Infantile Spasms, Symptomatic

\begin{tabular}{|c|c|c|c|c|c|c|c|c|c|c|c|}
\hline \multirow{2}{*}{$\begin{array}{c}\text { Group } 5 \\
\text { Subject } \\
\text { No. }\end{array}$} & \multirow{2}{*}{$\begin{array}{l}\text { Age } \\
\text { When } \\
\text { Tested } \\
\text { (mth.) }\end{array}$} & \multirow{2}{*}{$\underset{(\mathrm{kg} .)}{\text { Weight }}$} & \multirow[b]{2}{*}{ Insult } & \multirow{2}{*}{$\begin{array}{l}\text { Mental } \\
\text { Status }\end{array}$} & \multirow[b]{2}{*}{ EEG } & \multicolumn{6}{|c|}{ Metabolite Excretion (mg./24 hr.) } \\
\hline & & & & & & $\mathrm{XA}^{\star}$ & $\mathrm{XA}$ & $\mathbf{K}$ & KA & 3-OH K & 3-OH AA \\
\hline $\begin{array}{r}1 \\
2 \\
3 \\
29 \\
4 \\
5 \\
28 \\
33 \\
8 \\
30 \\
7 \\
31 \\
6 \\
9 \\
10 \\
11 \\
12 \\
14 \\
13 \\
15 \\
32 \\
16 \\
17 \\
18 \\
19 \\
23 \\
20 \\
24 \\
27 \\
25 \\
34 \\
26\end{array}$ & $\begin{array}{r}2 \\
2 \\
5 \\
5 \\
5 \cdot 5 \\
5 \\
6 \cdot 5 \\
6 \cdot 5 \\
7 \\
7 \\
7 \\
7 \\
7 \\
7 \\
7 \\
8 \\
8 \\
9 \\
9 \\
9 \\
10 \\
10 \\
11 \\
11 \\
11 \\
12 \\
13 \\
14 \\
16 \\
17 \\
24 \\
24 \\
29 \\
36 \\
8 \text { yr. } \\
11 \text { mth. }\end{array}$ & 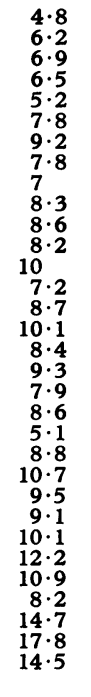 & 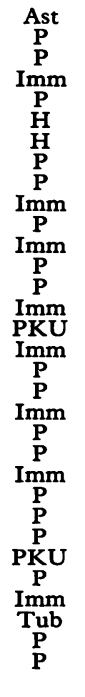 & $\begin{array}{l}G \\
G \\
G \\
G \\
G \\
M \\
M \\
G \\
G \\
G \\
G \\
G \\
N \\
G \\
G \\
M \\
M \\
M \\
G \\
G \\
G \\
G \\
G \\
M \\
G \\
M \\
G \\
G \\
G \\
G \\
G \\
G \\
G\end{array}$ & 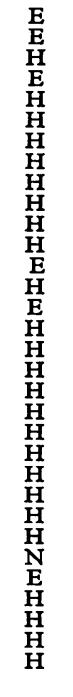 & $\begin{array}{r}0.5 \\
0.7 \\
3.1 \\
00.7 \\
2.6 \\
2.2 \\
1.7 \\
26.8 \\
52.9 \\
2.2 \\
3.0 \\
3.0 \\
3.4 \\
0.3 \\
2.8 \\
1.8 \\
0.5 \\
0.2 \\
3.4 \\
1.6 \\
2.9 \\
0.9 \\
26.0 \\
3.8 \\
7.6 \\
4.5 \\
0.3 \\
3.9 \\
1.6 \\
21.2 \\
2.2 \\
1.9\end{array}$ & $\begin{array}{l}2 \cdot 6 \\
0 \cdot 4\end{array}$ & $\begin{array}{r}22 \cdot 4 \\
0.3\end{array}$ & $\begin{array}{l}2 \cdot 5 \\
3 \cdot 2\end{array}$ & $0_{0}^{0 \cdot 6}$ & $\begin{array}{c}\mathbf{T r} \\
+++\end{array}$ \\
\hline
\end{tabular}

Insult: Ast $=$ brain cyst and astrocytoma, $P=$ perinatal injury, $\mathbf{I m m}=$ immunization, $\mathbf{H}=$ hypoglycaemia, $P K U=$ phenylketonuria Tub - tuberose sclerosis.

EEG, mental status, and metabolites as in Tables I-III.

$\mathbf{T r}=$ trace. 
TABLE VI

Tryptophan Load Test in Normal Subjects as Performed by Various Authors

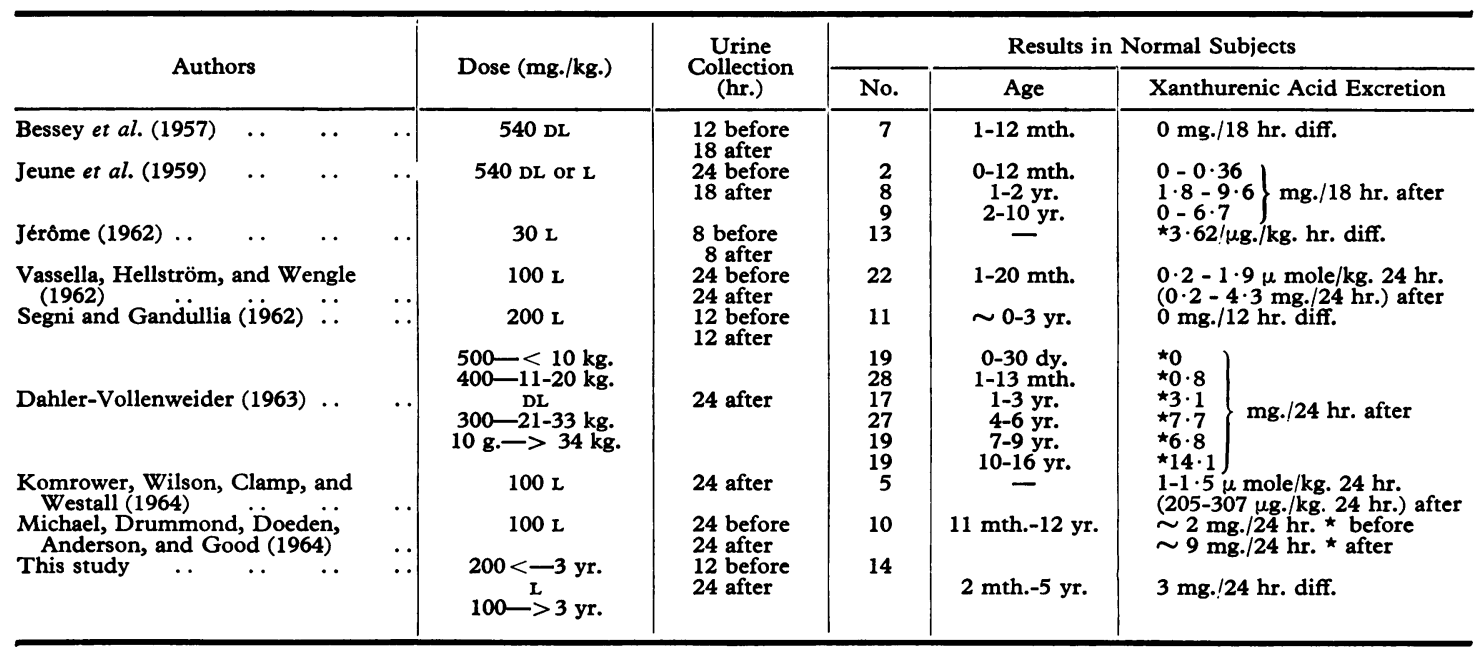

$\star$ Mean figures.

dimensional descending paper chromatography using butanol : acetic acid : water $(12: 3: 5)$ as first solvent and $20 \% \mathrm{KCl}$ as second solvent.

The value for the 12-hour period before tryptophan loading was doubled and subtracted from the figure obtained for the 24-hour collection after loading. The resulting difference is the figure used in all subsequent discussion. The other metabolites were identified under ultraviolet light by their characteristic fluorescence. They were cut out, eluted, and determined by modifications of the methods described by Coppini, Benassi, and Montorsi (1959) and Brown (1957). These will be the subject of a separate communication where the differences between the results given by the two methods of determining xanthurenic acid will be discussed. Electroencephalograms have been quantitated using the scoring system described by Jeavons and Bower (1961).

\section{Results}

Excretion of xanthurenic acid by healthy controls. Table I shows that subjects who are regarded as normal excrete less than $3 \mathrm{mg}$. xanthurenic acid per day. Whether or not this represents the upper limit of normal is still undecided. The factors affecting the excretion of xanthurenic acid following a tryptophan load are still not fully elucidated. The excretion certainly depends upon the dose of tryptophan and, as yet, the amount of xanthurenic acid that would be excreted by a human subject suffering from a slight but significant deficiency of pyridoxine is not known. Some of our findings in fact suggest that there are factors other than a deficiency of pyridoxine, in its usual sense, affecting the excretion of xanthurenic acid.
Although the excretion of xanthurenic acid depends, at least in adult subjects, on the amount of tryptophan given (Hughes and Raine, 1966), the evidence at present available suggests that this effect is not marked in children below the age of 4-5 years. Comparison of our findings with those previously published (Table VI) suggests that even with different dose schedules most authors find values for the excretion of xanthurenic acid of the same order as our own. In an earlier paper (Bower, 1961) the normal subjects and certain patients not suffering from infantile spasms were considered together as a control group, and none of these excreted more than $5 \mathrm{mg}$. xanthurenic acid. In the present study epileptic patients and those with other neurological disorders have not been included in the control group. None of the control group in the present study excreted more than $3 \mathrm{mg}$. per day, and this figure has therefore been used to divide normal from abnormal.

Excretion of xanthurenic acid by all clinical groups. The frequency with which the excretion of xanthurenic acid exceeded $3 \mathrm{mg}$. in 24 hours in each of the clinical groups, and in the two forms of infantile spasms considered together, is shown in Table VII.

It will be seen that an abnormal result was obtained in approximately the same proportion in each of the clinical groups. In no instance was the difference between the proportion of abnormal results in any two clinical groups significant. We, there- 
fore, conclude that the tryptophan load test is abnormal in about one-third of children with neurological disorders, whether or not these are accompanied by convulsions.

In each group there are a few results only slightly above $3 \mathrm{mg}$., the level at which the above analysis has been made. The greatest number of these borderline results is found in group 5 (infantile spasms of symptomatic origin), and it is of interest to consider the difference that would result if the results were analysed in terms of an upper limit of, say, $6 \mathrm{mg}$. The data have, therefore, been subjected to a similar analysis taking $6 \mathrm{mg}$., instead of $3 \mathrm{mg}$., as the dividing line for abnormal tests and the frequency of abnormal tests calculated. Although the latter is reduced in each clinical group (group 2, $25 \%$; group $3,33 \%$; group $4,15 \%$; group $5,16 \%$; group $(4+5), 15 \%)$, the differences between any pair of groups remains insignificant. For example the probabilities by the $\chi^{2}$ test that the differences could arise by chance are for groups 2 and 3, 0.8; for groups 4 and 5, 0.75; for groups $(4+5)$ and 3 , $0 \cdot 11$; for groups $(4+5)$ and $2,0 \cdot 75$; and for groups 4 and $3,0 \cdot 15$.

Two factors that may have further influenced these findings are a difference in age or sex distribution, and a difference in the incidence of anticonvulsant therapy within each clinical group. The mean and the range of ages in each group are: group 1, 2 months to 5 years, mean 20.5 months; group 2,4 months to 5.5 years, mean 27 months; group 3, 3 weeks to 12 years 8 months, mean 27 months; group 4, 3 months to 2 years 2 months, mean 9 months; group 5, 2 months to 8 years 11 months, mean 11 months. Thus there are slight differences in the means of the clinical groups, but these are insufficient to have had a substantial effect on the proportion of abnormal results. There was no difference in the frequency of abnormal results in males and females. The effect of anticonvulsant therapy, which in this series of patients included phenobarbitone, sodium phenytoin, and primidone, is examined in Fig. 1, where the range of xanthurenic

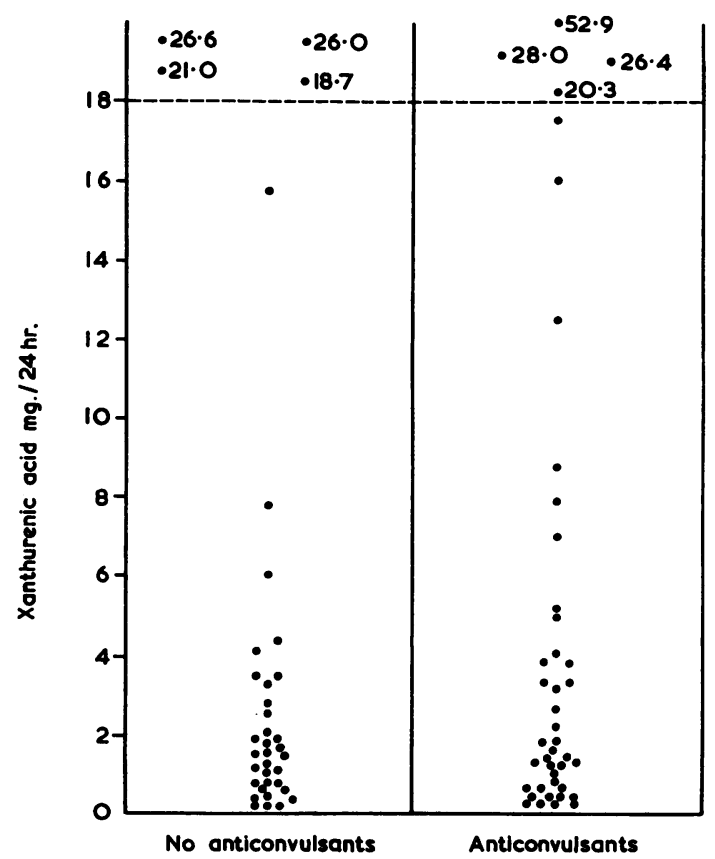

Fig. 1.-The effect of anticonvulsant drugs on xanthurenic acid excretion.

acid excretion in patients who had received such therapy is displayed against the range in untreated patients. These show no notable difference and it is concluded that anticonvulsant drugs have not affected the result of the tryptophan load test.

Excretion of metabolites other than xanthurenic acid. In Fig. 2 the excretion of xanthurenic acid, 3-hydroxykynurenine, kynurenic acid, and kynurenine are plotted, and 3-hydroxyanthranilic acid is shown either to be present or absent. All of these metabolites have been determined following paper chromatography. The patients have been divided initially on the basis of their xanthurenic acid excretion, determined by the simple ferric

TABLE VII

Frequency of High Xanthurenic Acid Excretion in Patients in Different Clinical Groups

\begin{tabular}{|c|c|c|c|c|c|}
\hline Clinical Group & & & No. of Cases & $\begin{array}{l}\text { Cases Excreting } \\
\text { More Than } 3 \mathrm{mg} \\
\text { Xanthurenic Acid }\end{array}$ & $\%$ Abnormal Tests \\
\hline $\begin{array}{l}\text { 2: CNS disorders without convulsions } \\
\text { 3: Epilepsy } \ldots \\
\text { 4: Infantile spasms_cryptogenic }\end{array}$ & $\begin{array}{l}\cdots \\
\cdots \\
\cdots\end{array}$ & $\begin{array}{ll}\cdots & \cdots \\
\cdots & \cdots \\
\cdots & \cdots \\
\end{array}$ & $\begin{array}{l}20 \\
46 \\
27 \\
32 \\
\end{array}$ & $\begin{array}{r}9 \\
20 \\
7 \\
12\end{array}$ & $\begin{array}{l}45 \\
43 \\
26 \\
37\end{array}$ \\
\hline $4+5$, Infantile spasms-total & .. & .. $\quad$. & 59 & 19 & 32 \\
\hline
\end{tabular}

The significance of the differences between various groups has been subjected to the $\chi^{2}$ test. $p$ values for groups 2 and $3,0 \cdot 85$; groups 4 and $5,0.55 ;$ groups $(4+5)$ and $3,0.35 ;$ groups $(4+5)$ and $2,0 \cdot 45$; and groups 4 and $2,0 \cdot 35$. 


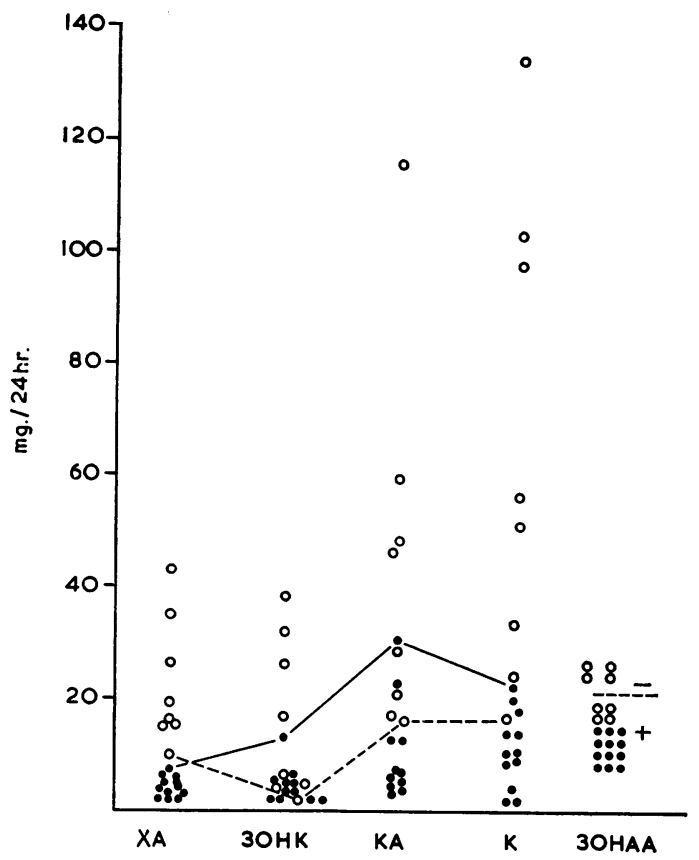

FIG. 2.-Excretion of metabolites following a tryptophan load. Subjects in whom xanthurenic acid was normal, when determined by the iron method, are denoted by dots: those who had an abnormal result are denoted by open circles. The highest dot and the lowest circle in each column are joined by a solid and a dotted line, respectively. The metabolites reading from the left are xanthurenic acid, 3-hydroxykynurenine, kynurenic acid, kynurenine, and 3-hydroxyanthranilic acid.

alum method without chromatographic purification. Those excreting less than $3 \mathrm{mg}$. by this method are marked by a dot, and those excreting more than this by a circle. A solid line marks the upper limit of those subjects excreting less than $3 \mathrm{mg}$. xanthurenic acid, and a dotted line the lower limit of those excreting more than $3 \mathrm{mg}$. xanthurenic acid. Thus an area is outlined in which the excretion of the other metabolites is not in accord with the excretion of xanthurenic acid.

The determination of xanthurenic acid by the simple ferric alum method has been criticized, since the reaction is not very specific. It is interesting, therefore, to find that the excretion of xanthurenic acid following paper chromatography (Fig. 2, column 1) is in complete accord with that by the simpler method. With the other metabolites, however, there is in each case some overlap. This is least for kynurenine, and slightly more for kynurenic acid and 3-hydroxyanthranilic acid, but in the case of 3-hydroxykynurenine the overlap is substantial.

Thus, examination of the other metabolites usually reinforces the conclusion drawn from the determination of xanthurenic acid by the simple procedure. It is considered that, where the facilities for the more complex chromatographic determinations are not available, useful information can be obtained by using the ferric alum procedure alone.

EEG findings. In infantile spasms the EEG is always abnormal. The degree of abnormality in each record was quantitated by Dr. P. M. Jeavons using a scoring system previously described (Jeavons and Bower, 1961). A score of 2-8 is labelled epileptic (i.e. non-hypsarrhythmic) and a score of 9-30 is hypsarrhythmic, the most abnormal EEG pattern in epilepsy. Table VIII shows that hypsarrhythmic records were found equally commonly in those patients with a normal and an abnormal xanthurenic acid excretion. In the epileptic group (group 3) there are more epileptic and fewer normal records in the patients with increased xanthurenic acid excretion than in those with a normal excretion. With this exception there is no evidence of a significant correlation between the EEG and the biochemical abnormalities.

\section{TABLE VIII}

Tryptophan Load Test in Relation to EEG

\begin{tabular}{|c|c|c|c|c|c|c|c|c|c|c|}
\hline \multirow{3}{*}{\multicolumn{2}{|c|}{ Clinical Group }} & & \multicolumn{4}{|c|}{ TLT Normal } & \multicolumn{4}{|c|}{ TLT Abnormal } \\
\hline & & & \multirow{2}{*}{$\begin{array}{l}\text { Total } \\
\text { Cases }\end{array}$} & \multicolumn{3}{|c|}{ EEG } & \multirow{2}{*}{$\begin{array}{l}\text { Total } \\
\text { Cases }\end{array}$} & \multicolumn{3}{|c|}{ EEG } \\
\hline & & & & $\begin{array}{l}\text { Hyps- } \\
\text { arrhythmia }\end{array}$ & Epileptic & $\begin{array}{l}\text { Normal or } \\
\text { No Specific } \\
\text { Abnormality }\end{array}$ & & $\begin{array}{l}\text { Hyps- } \\
\text { arrhythmia }\end{array}$ & Epileptic & $\begin{array}{l}\text { Normal or } \\
\text { No Specific } \\
\text { Abnormality }\end{array}$ \\
\hline $\begin{array}{l}\text { 2: CNS disorders } \\
\text { 3: Epilepsy } \\
\text { 4: Cryptogenic spasms } \\
5: \text { Symptomatic spasms } \\
\text { 4 + 5: Total spasms }\end{array}$ & $\begin{array}{l}\cdots \\
\cdots \\
\cdots\end{array}$ & $\begin{array}{l}\cdots \\
\cdots \\
\cdots \\
\cdots\end{array}$ & $\begin{array}{l}10 \\
26 \\
20 \\
20 \\
40\end{array}$ & $\begin{array}{r}0 \\
3 \\
16 \\
15 \\
31\end{array}$ & $\begin{array}{r}0 \\
13 \\
4 \\
4 \\
8\end{array}$ & $\begin{array}{r}10 \\
10 \\
0 \\
1 \\
1\end{array}$ & $\begin{array}{r}9 \\
20 \\
7 \\
12 \\
19\end{array}$ & $\begin{array}{r}0 \\
1 \\
3 \\
10 \\
13\end{array}$ & $\begin{array}{c}2^{\star} \\
17 \\
4 \\
2 \\
6\end{array}$ & $\begin{array}{l}7 \\
2 \\
0 \\
0 \\
0\end{array}$ \\
\hline
\end{tabular}

* These two patients showed a single or a few brief spike or spike and wave bursts only. 
Metabolism of Tryptophan in Childhood Epilepsy

TABLE IX

Tryptophan Load Test in Relation to Mental Status

\begin{tabular}{|c|c|c|c|c|c|c|c|c|c|}
\hline \multirow{3}{*}{ Clinical Group } & & \multicolumn{4}{|c|}{ TLT Normal } & \multicolumn{4}{|c|}{ TLT Abnormal } \\
\hline & & \multirow{2}{*}{$\begin{array}{l}\text { Total } \\
\text { Cases }\end{array}$} & \multicolumn{3}{|c|}{ Retardation } & \multirow{2}{*}{$\begin{array}{l}\text { Total } \\
\text { Cases }\end{array}$} & \multicolumn{3}{|c|}{ Retardation } \\
\hline & & & Gross & Moderate & Normal & & Gross & Moderate & Normal \\
\hline $\begin{array}{l}\text { 2: CNS disorders } \\
\text { 3: Epilepsy } \ldots \\
\text { 4: Cryptogenic spasms } \ldots \\
\text { 5: Symptomatic spasms } \\
4+5: \text { Total spasms }\end{array}$ & $\begin{array}{l}\cdots \\
\cdots \\
\cdots \\
\cdots\end{array}$ & $\begin{array}{l}10 \\
26 \\
20 \\
20 \\
40\end{array}$ & $\begin{array}{r}4 \\
8 \\
15 \\
15 \\
30\end{array}$ & $\begin{array}{l}2 \\
9 \\
4 \\
4 \\
8\end{array}$ & $\begin{array}{l}4 \\
9 \\
1 \\
1 \\
2\end{array}$ & $\begin{array}{r}9 \\
20 \\
7 \\
12 \\
19\end{array}$ & $\begin{array}{r}1 \\
5 \\
5 \\
10 \\
15\end{array}$ & $\begin{array}{l}6 \\
6 \\
2 \\
2 \\
4\end{array}$ & $\begin{array}{l}2 \\
9 \\
0 \\
0 \\
0\end{array}$ \\
\hline
\end{tabular}

Mental status. Just as there is no correlation of xanthurenic acid with epilepsy, so none has been demonstrated with mental subnormality. The latter was graded as mild, moderate, or gross, corresponding approximately to development quotients $70-85,35-70$, and less than 35 , respectively. Table IX shows that for all clinical groups the distribution of the grades of subnormality was similar in both biochemical groups.

Aetiology. Possible correlations of either biochemical or EEG findings with the aetiology of the infantile spasms in the symptomatic group 5 have also been sought. Of the 18 patients with an important perinatal factor in the history, 10 had an abnormal xanthurenic acid excretion, whereas only 1 of 9 in the immunization group did so. This suggests a correlation between perinatal insult and abnormal xanthurenic acid excretion, but the fact that 7 of the 27 patients in the cryptogenic group, where no such insult was admitted, also had the biochemical abnormality renders the significance of the correlation extremely doubtful.

\section{Discussion}

The finding of abnormal xanthurenic acid excretion after tryptophan loading was reported in all of 5 cases of infantile spasms studied by Cochrane (1959), in 3 of 4 patients studied by Jeune, Cotte, Hermier, Yasse, and Leriche (1959), and in 7 of 10 patients studied by Segni and Gandullia (1962). Hellström and Vassella (1962) studied 14 patients of whom 5 gave an abnormal result, but when 2 of these 5 were repeated, a normal result was obtained. Our own earlier work (Bower, 1961; Bower and Hughes, 1961) also showed a proportion of abnormal results in patients with infantile spasms.

More recently, patients with forms of epilepsy other than infantile spasms have been found to have abnormal xanthurenic acid excretion following a tryptophan load, notably 1 of 2 patients studied by Segni and Gandullia (1962), 9 of 38 patients studied by Hottinger, Berger, and Krauthammer
(1964), and 26 of 43 patients with cryptogenic epilepsy studied by Hagberg, Hamfelt, and Hansson (1965). Similar results have been reported by ourselves (Bower, Hughes, and Raine, 1965).

The only study in which patients with chronic cerebral disorders but no epilepsy have been examined in this way is that of Hottinger et al. (1964) who found abnormal xanthurenic acid excretion in 5 of 35 subjects. Hagberg et al. (1965) have studied patients with progressive brain disorder, not all of whom had convulsions, but from their publication it is not possible to determine the frequency of abnormal tests in the latter group alone.

The results reported in the present study show that not only is there no correlation between the aetiological subgroup of infantile spasms or the clinical variety of epilepsy and the level of xanthurenic acid excretion, but the presence or absence of epilepsy itself seems unrelated to xanthurenic acid excretion. Before accepting such a conclusion, however, we should consider whether the xanthurenic acid excretion bears any relation to the EEG findings. If there is any correlation between childhood epilepsy and xanthurenic acid excretion, we should expect abnormal excretion to occur mainly in those patients with the more abnormal EEGs. No such correlation was found however, nor was there any with the degree of mental subnormality or with the associated disorders in the symptomatic group of infantile spasms.

Thus the tryptophan load test can provide no help in the differential diagnosis of cerebral disorders or of convulsive disorders. It may, however, provide an important part of the investigation of two rare conditions, namely a dietary deficiency of pyridoxine and pyridoxine dependency.

In view of the apparently obvious relationship of the increased xanthurenic acid excretion (in response to a tryptophan load) to pyridoxine deficiency, the effects of administering this vitamin have been particularly disappointing. Although in every case this biochemical abnormality has been corrected, there has been little or no clinical improvement in 
the subjects treated. It was therefore important to examine further the extent to which the biochemical abnormality in these subjects is related to pyridoxine.

To this end several other tryptophan metabolites dependent either directly or indirectly upon pyridoxine have been studied. These include kynurenine, kynurenic acid, 3-hydroxykynurenine, and 3-hydroxyanthranilic acid, and their relation to the vitamin and to xanthurenic acid is shown in Fig. 3. It can be seen that if the activity of the enzyme kynureninase, which is responsible for the conversion of 3-hydroxykynurenine to 3-hydroxyanthranilic acid and which is very dependent upon pyridoxine, is deficient, then 3-hydroxykynurenine and kynurenine will accumulate and the two products of side-reaction, kynurenic acid and xanthurenic acid, will be more prominent.

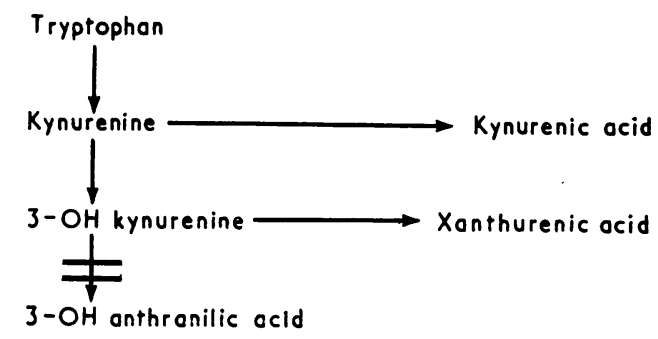

FIG. 3.-Some steps in the metabolism of tryptophan. The double bar shows the one most dependent upon pyridoxine.

Our present study shows that when the xanthurenic acid excretion is greater than normal, in many instances the excretion of the other four metabolites studied supports the belief that the over-all biochemical defect is associated with some aspect of pyridoxine utilization. The precise nature of this defect is still quite unknown, but the biochemical response to various forms of treatment is relevant to this question and this will be considered in a subsequent paper.

\section{Summary}

The tryptophan load test was applied to 139 children comprising the following clinical groups: healthy controls; children with chronic cerebral disorders unassociated with epilepsy; children with epilepsy other than infantile spasms; and children with infantile spasms, subdivided into cryptogenic and symptomatic groups. The excretion of xanthurenic acid, and in some cases of four other metabolites, was determined. Results were abnormal in about one-third of patients in each group. There was no correlation of abnormal results with the presumed aetiology, the degree of mental subnormality, or the severity of EEG abnormality, and the results appeared to be unaffected by anticonvulsant therapy. The excretion of metabolites other than xanthurenic acid supports the view that an abnormal result in these patients is related to a defect of pyridoxine utilization.

We have found the tryptophan load test to be of little value in the investigation of convulsive disorders in childhood.

We are grateful to Professor D. V. Hubble for his interest and help, to the physicians of the Children's Hospital, and the paediatricians of the Birmingham Regions for allowing us to investigate their patients, and to the nursing staff for the care they have taken with the tests. Our thanks are also due to Dr. P. M. Jeavons for his analysis of the electroencephalograms. This study was generously supported by the Endowment Fund of the United Birmingham Hospitals and the League of Friends of the Children's Hospital.

\section{REFERENCES}

Adams, D. J. D., Bessey, O. A., Bussey, D. R., and Hansen, A. E. (1954). Vitamin $B_{6}$ requirement in relation to convulsive seizures in infants. Amer. F. Dis. Child., 88, 623.

Bessey, O. A., Adams, D. J. D., and Hansen, A. E. (1957). Intake of vitamin $\mathbf{B}_{6}$ and infantile convulsions: $\mathbf{A}$ first approximation of requirements of pyridoxine in infants. Pediatrics, 20, 33.

Bower, B. D. (1961). The tryptophan load test in the syndrome of infantile spasms with oligophrenia. Proc. roy. Soc. Med., 54, 540.

-, and Hughes, P. A. M. (1961). The significance of the tryptophan load test in infantile spasms with oligophrenia. Proc. Ass. clin. Biochem., 1, 72.

phan metabolism. In Biochemical Approaches to Mental Handicap in Children, ed. J. D. Allan and K. S. Holt, p. 28. Livingstone, Edinburgh and London.

Brown, R. R. (1957). The isolation and determination of urinary hydroxykynurenine. f. biol. Chem., 227, 649.

Cochrane, W. A. (1959). The syndrome of infantile spasms and progressive mental deterioration related to amino acid and pyridoxine metabolism. IX International Congress Pediatrics, Montreal.

Coppini, D., Benassi, C. A., and Montorsi, M. (1959). Quantitative determination of tryptophan metabolites (via kynurenine) in biologic fluids. Clin. Chem., 5, 391.

Coursin, D. B. (1954). Convulsive seizures in infants with pyridoxine-deficient diet. F. Amer. med. Ass., 154, 406

(1955). Vitamin $B_{6}$ deficiency in infants; a follow-up study. Amer. F. Dis. Child., 90, 344.

Dahler-Vollenweider, E. M. (1963). Xanthurensäureausscheidungen nach Tryptophanbelastung bei Kindern. Ann. paediat. (Basel), 200, 333.

Garty, R., Yonis, Z., Braham, J., and Steinitz, K. (1962). Pyridoxine-dependent convulsions in an infant. Arch. Dis. Childh., 37, 21.

Hagberg, B., Hamfelt, A., and Hansson, O. (1965). Tryptophantolerance tests and vitamin $\mathbf{B}_{6}$ (pyridoxine) metabolism in epileptic children. Develop. Med. Child Neurol., 7, 50.

Hellström, B., and Vassella, F. (1962). Tryptophan metabolism in infantile spasm. Acta paediat. (Uppsala), 51, 665.

Hottinger, A., Berger, H., and Krauthammer, W. (1964). Klinische Beobachtungen zum Problem des Vitamin-B ${ }_{6}$-Metabolismus. Schweiz. med. Wschr., 94, 221.

Hughes, P. A. M., and Raine, D. N. (1966). In vivo formation of pyridoxal phosphate Schiff's base-an inherent defect in the tryptophan load test. Clin. chim. Acta, 14, 399. 
Hunt, A. D., Stokes, J., McCrory, W. W., and Stroud, H. H. (1954). Pyridoxine dependency: report of a case of intractable convulsions in an infant controlled by pyridoxine. Pediatrics, 13, 140.

Jeavons, P. M., and Bower, B. D. (1961). The natural history of infantile spasms. Arch. Dis. Childh., 36, 17.

—, and - (1964). Infantile spasms. Little Club Clin. Develop. Med., 15.

Jérôme, H. (1962). Anomalies du métabolisme du tryptophane dans la maladie mongolienne. Bull. mém. Soc. Méd. Hôp. Paris, 113, 168.

Jeune, M., Cotte, J., Hermier, M., Yasse, L., and Leriche, Mme. (1959). L'épreuve de charge au tryptophane comme moyen de détection des apyridoxinoses chez l'enfant. Pédiatrie, 14, 853.

Komrower, G. M., Wilson, V., Clamp, J. R., and Westall, R. G. (1964). Hydroxykynureninuria. A case of abnormal tryptophan metabolism probably due to a deficiency of kynureninase. Arch. Dis. Childh., 39, 250.

Marie, J., Hennequet, A., Lyon, G., Debris, P., and Le Balle, J. C. (1959). Les crises convulsives pyridoxino-sensibles du nouveau né et du nourrison. Sem. Hôp. Paris, 35, 1411.

May, C. D. (1954). Vitamin $B_{6}$ in human nutrition: a critique and an object lesson. Pediatrics, 14, 269.

Michael, A. F., Drummond, K. N., Doeden, D., Anderson, J. A., and Good, R. A. (1964). Tryptophan metabolism in man. f. clin. Invest., 43, 1730.

Molony, C. J., and Parmelee, A. H. (1954). Convulsions in young infants as a result of pyridoxine (Vitamin $\mathbf{B}_{6}$ ) deficiency. 7. Amer. med. Ass., 154, 405.

Scriver, C. R. (1960). Vitamin $B_{6}$-dependency and infantile convulsions. Pediatrics, 26, 62.

- and Hutchison, J. H. (1963). The vitamin $\mathbf{B}_{6}$ deficiency syndrome in human infancy: biochemical and clinical observations. ibid., 31, 240.

Segni, G., and Gandullia, E. (1962). La prova del carico di triptofano nella prima infanzia. Minerva pediat., 14, 1095.

Snyderman, S. E., Holt, L. E., Carretero, R., and Jacobs, K. (1953), Pyridoxine deficiency in the human infant. F. clin. Nutr., 1, 200.

Sokoloff, L., Lassen, N. A., McKhann, G. M., Tower, D. B., and Albers, W. (1959). Effects of pyridoxine withdrawal on cerebral circulation and metabolism in a pyridoxine-dependent child. Nature (Lond.), 183, 751.

Vassella, F., Hellström, B., and Wengle, B. (1962). Urinary excretion of tryptophan metabolites in the healthy infant. Pediatrics, 30, 585.

Waldinger, C., and Berg, R. B. (1963). Signs of pyridoxine dependency manifest at birth in siblings. ibid., 32, 161. 